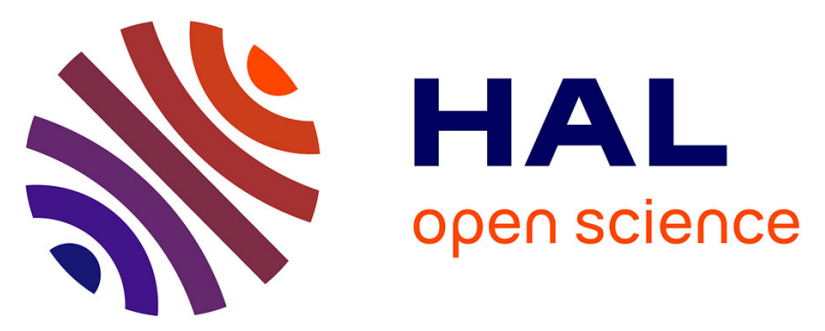

\title{
Are breast conservation and mastectomy equally effective in the treatment of young women with early breast cancer? Long-term results of a population-based cohort of 1,451 patients aged $\leq 40$ years
}

Maurice J. C. Sangen, Fenneke M. M. Wiel, Philip M. P. Poortmans, Vivianne C. G. Tjan-Heijnen, Grard A. P. Nieuwenhuijzen, Rudi M. H. Roumen, Miranda F. Ernst, M. Cathelijne B. J. E. Tutein Nolthenius-Puylaert, Adri C. Voogd

\section{To cite this version:}

Maurice J. C. Sangen, Fenneke M. M. Wiel, Philip M. P. Poortmans, Vivianne C. G. Tjan-Heijnen, Grard A. P. Nieuwenhuijzen, et al.. Are breast conservation and mastectomy equally effective in the treatment of young women with early breast cancer? Long-term results of a population-based cohort of 1,451 patients aged $\leq 40$ years. Breast Cancer Research and Treatment, 2010, 127 (1), pp.207-215. 10.1007/s10549-010-1110-x . hal-00594467

\section{HAL Id: hal-00594467 https://hal.science/hal-00594467}

Submitted on 20 May 2011

HAL is a multi-disciplinary open access archive for the deposit and dissemination of scientific research documents, whether they are published or not. The documents may come from teaching and research institutions in France or abroad, or from public or private research centers.
L'archive ouverte pluridisciplinaire HAL, est destinée au dépôt et à la diffusion de documents scientifiques de niveau recherche, publiés ou non, émanant des établissements d'enseignement et de recherche français ou étrangers, des laboratoires publics ou privés. 


\section{Are breast-conservation and mastectomy}

\section{equally effective in the treatment of young}

\section{women with early breast cancer?}

\section{Long-term results of a population based cohort of 1451}

\section{patients aged $\leq 40$ years}

Maurice J.C. van der Sangen ${ }^{1^{*}}$, Fenneke M.M. van de Wiel ${ }^{2^{*}}$, Philip M.P. Poortmans ${ }^{3}$, Vivianne C.G. Tjan-Heijnen ${ }^{4}$, Grard A.P. Nieuwenhuijzen ${ }^{5}$, Rudi M.H. Roumen ${ }^{6}$, Miranda F. Ernst ${ }^{7}$, M. Cathelijne B.J.E. Tutein Nolthenius-Puylaert ${ }^{8}$, Adri C. Voogd ${ }^{9,10}$

${ }^{1}$ Department of Radiotherapy, Catharina Hospital, Eindhoven, The Netherlands

${ }^{2}$ Faculty of Health, Medicine and Life Sciences, Maastricht University, Maastricht, The Netherlands

${ }^{3}$ Department of Radiotherapy, Dr Bernard Verbeeten Institute, Tilburg, The Netherlands

${ }^{4}$ Division of Medical Oncology, Department of Internal Medicine, Research Institute Growth and Development (GROW), Maastricht University Medical Centre, Maastricht, The Netherlands

${ }^{5}$ Department of Surgery, Catharina Hospital, Eindhoven, The Netherlands

${ }^{6}$ Department of Surgery, Máxima Medical Centre, Veldhoven, The Netherlands

${ }^{7}$ Department of Surgery, Jeroen Bosch Hospital, 's Hertogenbosch, The Netherlands

${ }^{8}$ Department of Pathology, Elkerliek Hospital, Helmond, The Netherlands 
${ }^{9}$ Department of Epidemiology, Research Institute Growth and Development (GROW), Maastricht University Medical Centre, Maastricht, The Netherlands

${ }^{10}$ Eindhoven Cancer Registry, Eindhoven, The Netherlands

* M.J.C. van der Sangen and F.M.M. van de Wiel contributed equally to this work

Address for correspondence:

Adri C. Voogd, Department of Epidemiology, Maastricht University, PO Box 616, 6200 MD, Maastricht, The Netherlands, Tel. : +31 43 3882387; Fax: +31 433884128 ;

E-mail: adri.voogd@epid.unimaas.nl

Running head: Breast-conserving therapy and mastectomy in patients aged $\leq 40$ years 


\section{Abstract}

To compare the effectiveness of breast-conserving therapy (BCT) and mastectomy in a large cohort of women aged $\leq 40$ years with early-stage breast cancer, all women aged $\leq 40$ years, treated for early-stage breast cancer in the southern part of the Netherlands between 1988 and 2005, were identified. A total of 562 patients underwent mastectomy and 889 patients received BCT. During follow-up, 23 patients treated with mastectomy and 135 patients treated with BCT developed a local relapse without previous or simultaneous evidence of distant disease. The local relapse risk for patients treated with mastectomy was $4.4 \%$ (95\% confidence interval (Cl), 2.4-6.4) at 5 years and reached a plateau after 6 years at $6.0 \%(95 \% \mathrm{Cl}, 3.5-$ 8.5). After BCT, the 5-, 10- and 15-year risks were 8.3\% (95\% Cl, 6.3-10.5), 18.4\% $(95 \% \mathrm{Cl}, 15.0-21.8)$ and $28.2 \%(95 \% \mathrm{Cl}, 23.0-33.4)$, respectively $(\mathrm{P}<.0001)$. Adjuvant systemic therapy following BCT reduced the 15-year local relapse risk from 32.9\% (95\% $\mathrm{Cl}, 26.7-39.1)$ to $16.1 \%(95 \% \mathrm{Cl}, 9.1-23.1),(P=.0007)$. In conclusion, local tumor control in young patients with early-stage breast cancer is worse after BCT than after mastectomy. Adjuvant systemic therapy significantly improves local control following BCT and also for that reason it should be considered for most patients $\leq 40$ years. Long-term follow-up is highly recommended for young patients after BCT, because even with systemic treatment an annual recurrence risk of $1 \%$ remains up to 15 years after treatment. 


\section{Introduction}

Multiple randomized controlled trials have shown that survival rates for patients with early-stage breast cancer are comparable after breast-conserving therapy (BCT) and mastectomy [1-5]. Consequently, BCT is now widely accepted as a local treatment for early-stage breast cancer.

Some doubts still remain concerning the treatment of young women since young age has been shown to be an independent risk factor for local relapse after $\mathrm{BCT}$, much more than after mastectomy [6-10]. The 10-year local relapse rate for women aged $\leq 40$ years varies between $19 \%$ and $35 \%$ after BCT and between $7 \%$ and $12 \%$ after mastectomy $[8,9,11,12,6]$. In two previous reports concerning women $\leq 40$ years we found 5 - and 10 -year actuarial local relapse rates of $9 \%$ and $17.9 \%$, respectively, after BCT [13] and of 5.6\% and $7.3 \%$ after mastectomy [14].

Only $5 \%$ to $10 \%$ of all women with breast cancer is aged 40 years or younger. Because of this relatively low incidence, subgroup analyses of the randomized controlled trials could not confirm whether BCT is as safe as mastectomy in the treatment of early-stage breast cancer in young women. Even by pooling data derived from all available trials, the number of young patients would be too small to draw firm conclusions. Therefore, evidence for the safety of BCT was searched in a few non-randomized studies [15-17]. Limitations of these studies are the relatively small number of patients, ranging from 540 to 668 , insufficient information on the risk factors of local relapse and a follow-up time up limited to only 10 years. Therefore, we evaluated a large cohort of 1451 patients aged $\leq 40$ years with a sufficiently long follow-up to determine treatment results up to 15 years. 


\section{Patients and methods}

Patients

Patient data were obtained from the population-based Eindhoven Cancer Registry (ECR). This serves a population of approximately 2.4 million inhabitants in the south of the Netherlands and records data on all patients with newly diagnosed cancer since 1955 . These data were compared to data derived from the two radiotherapy departments in this region, the Catharina Hospital in Eindhoven and the Dr. Bernard Verbeeten Institute in Tilburg. Records of patients who did not receive radiotherapy after mastectomy were provided by the surgical departments of the 10 regional hospitals.

Only patients with stage I or II breast cancer (pT1-2, N0-2, M0) were considered eligible for the study. The ECR identified 846 patients aged $\leq 40$ years that underwent mastectomy between 1988 and 2005, from which 745 medical records were available. For the other 101 patients records were either missing or incomplete after digitalising paper medical records. Over the same period, 937 patients aged $\leq 40$ years received BCT, for whom all patient records were available. The medical files were reviewed to extract information with respect to patient-, tumorand treatment characteristics as well as to outcome. After exclusion of 122 patients with stage III or IV breast cancer, 44 patients with neo-adjuvant systemic treatment, 8 patients with synchronous bilateral breast cancer, 19 patients with non-invasive breast cancer, and 8 patients without radiotherapy of the breast following breastconserving surgery, 562 patients remained available for analysis in the mastectomy group and 889 patients in the BCT group. 


\section{Treatment}

Patients underwent mastectomy or BCT. All patients received either a sentinel lymph node procedure or an axillary lymph node dissection. Indications for locoregional radiotherapy after mastectomy included an involved lymph node in the apex of the axilla, fixed axillary lymph nodes or $\geq 4$ lymph node metastases. This locoregional radiotherapy was given to a dose of 46 to 50 Gy. In case of an incomplete tumor resection of the primary breast tumor, a boost to a dose of 13.8 to 26 Gy was given to part of the chest wall. Until 2002 the guidelines also recommended the use of postmastectomy radiotherapy for patients with extracapsular lymph node invasion. In the framework of BCT, patients received 46 to 50 Gy to the whole breast, in 796 patients (91.8\%) followed by a boost of 10 to 26 Gy to the primary tumor bed. Indications for locoregional radiotherapy after breast conserving surgery were similar to those after mastectomy.

Before 1998, adjuvant systemic treatment was based on regional guidelines and was recommended only for patients with involved axillary lymph nodes. In 1998, a new national guideline was published [18], based on the St. Gallen guidelines $[19,20]$, after which lymph node-negative patients with high-risk breast cancer were advised to receive adjuvant systemic treatment, depending on size, grade, and hormone receptor status. In 2001, the guidelines were updated, recommending adjuvant systemic treatment also for most patients aged $\leq 35$ years, irrespective of their lymph node status.

The standard chemotherapy regimen consisted of cyclophosphamide, methotrexate and fluorouracil (CMF) in the early years of the study period and of 
anthracycline-containing regimens thereafter. From 1988 until 2001 there was no strict guideline for the use of hormonal therapy for pre-menopausal patients who had receptor-positive tumors. After 2001 hormonal therapy was recommended for all receptor positive high-risk patients. In the study period, trastuzumab was not yet implemented in the adjuvant setting.

Follow-up

For patients treated with mastectomy, follow-up was completed until January $1^{\text {st }}$, 2007 or death. Median duration of follow-up was 7.4 years. Patients receiving BCT were followed up until death or January $1^{\text {st }}, 2008$. Median duration of follow-up was 9.5 years. Seventy-three patients (5.0\%) were lost to follow-up, meaning that their last contact with the surgeon, radiation oncologist or general practitioner was before January $1^{\text {st }}, 2007$ in case of mastectomy or January $1^{\text {st }}, 2008$ in case of BCT. The median follow-up for these patients was 8.9 years and they have been included in the analysis until their last date of contact.

\section{Methods}

The endpoints of this study were local relapse, distant recurrence and death. Local relapse was defined as reappearance of tumor growth in the treated breast or overlying skin or, in case of mastectomy, on the ipsilateral chest wall. The time to an event was estimated using the life-table method and was considered to be the interval between the date of primary treatment and occurrence of the event. Observation time was censored at January $1^{\text {st }}, 2007$ for patients undergoing 
mastectomy and January $1^{\text {st }}, 2008$ for those undergoing BCT, or death or the last date of contact for patients who were lost to follow-up. Local relapses that were diagnosed after distant metastases or with synchronous distant disease were not counted as events in the survival analyses, because these are considered to be of little clinical importance and because the risk of underreporting is high. These patients were censored at the date of diagnosis of distant disease.

A multivariate analysis was carried out using Cox proportional hazard model to determine the impact of the type of surgery on the risk of distant recurrence, adjusting for age at diagnosis, the period of diagnosis, tumor size, axillary nodal status and use of adjuvant systemic treatment.

\section{Results}

Patient, tumor and treatment characteristics

Table 1 lists the patient, tumor and treatment characteristics of the study population. Median age at diagnosis was 37.2 years for patients treated with mastectomy and 37.4 years for those treated with BCT. As expected, despite the restriction to early stage breast cancer, patients treated with mastectomy generally had worse prognostic factors, when compared to those treated with BCT (Table 1). Because of worse prognostic factors, patients treated with mastectomy more often received systemic therapy $(\mathrm{P}<0.0001)$. The proportion of young women undergoing BCT decreased from $69 \%$ in the period $1988-1993$ to $55 \%$ in the period $2000-2005$ $(P<0.0001)$. 
After mastectomy, 37\% of the patients received radiotherapy. The overall proportion of patients aged $\leq 40$ years receiving adjuvant systemic treatment increased from 35\% in the period 1988-1993 to 77\% in the period 2000-2005 (Figure 1).

Local tumor control

Of the 131 local relapses occurring after BCT, 61 (45\%) were diagnosed within 5 years, 44 (33\%) between 5 and 10 years, and 30 (22\%) thereafter. Twenty-three local relapses occurred after mastectomy, of which 19 (83\%) within 5 years and 4 (17\%) between 5 and 10 years after treatment. No local relapses were diagnosed more than 6 years after mastectomy.

Of the local relapses after BCT, 19 (14\%) were in situ and $111(82 \%)$ were invasive tumors. From five patients this information was missing. Of the 23 local relapses after mastectomy, 22 were invasive and one was an in situ lesion. Ninety (67\%) of the 135 local relapses following BCT were localized at or near the site of the primary tumor, 15 (11\%) were localized elsewhere in the breast, seven (5\%) were diffuse and one involved the skin. For 22 patients information on the location of the local relapse was missing.

The actuarial risk of local relapse was significantly worse for patients undergoing BCT compared to patients undergoing mastectomy (Figure 2a). The 5-, 10- and 15-year local relapse rates were $8.3 \%(95 \% \mathrm{Cl}, 6.3-10.5), 18.3 \%(95 \% \mathrm{Cl}$, 14.9-21.7) and $27.9 \%(95 \% \mathrm{Cl}, 22.9-32.9)$, respectively. For the patients who underwent mastectomy, these figures were $4.4 \%(95 \% \mathrm{Cl}, 2.4-6.4)$ after 5 years and $6.0 \%(95 \% \mathrm{Cl}, 3.5-8.5)$ after 10 and after 15 years of follow-up. When also taking into 
account the local relapses that occurred simultaneously with distant metastases (11 after mastectomy and 19 after BCT), the 5-, 10- and 15-year rates were $10.3 \%$ (95\% Cl, 8.1-12.5), 20.4\% (95\% Cl, 17.0-23.8) and 30.1\% (95\% Cl, 25.0-35.2), respectively, after $\mathrm{BCT}$ and $6.4 \%(95 \% \mathrm{Cl}, 4.1-8.7), 8.2 \%(95 \% \mathrm{Cl}, 5.4-11.0)$ and $8.2 \%(95 \% \mathrm{Cl}, 5.4-11.0)$ after mastectomy $(\mathrm{P}<0.0001)$.

A significant improvement was observed in the local control rate after BCT during the study period (Table 2). A stratified analysis according to axillary nodal status showed that this improvement did only occur in patients with negative lymph nodes. This appeared to be related to the increased use of systemic therapy over the years, as the risk for local relapse was significantly lower for patients who received adjuvant systemic treatment (Table 2, Fig 2b). A higher local relapse risk was observed for patients whose excision of the primary tumor was incomplete or doubtful, as compared to those with a complete excision (Table 2). No significant associations were found between the risk of local relapse after BCT and tumor size and between the different age groups ( $<30,30-35$ and $35-40$ years) (Table 2$)$. The local relapse rate was significantly higher after BCT in the patient group without a boost dose of radiotherapy to the tumor bed (Table 2). No dose-effect relationship was observed for the patients receiving a boost dose.

Distant recurrence-free and overall survival

No statistically significant difference in distant recurrence-free survival was observed between the patients undergoing BCT or mastectomy (Figure 3). The 10-year distant recurrence-free survival rates were $71.0 \%(95 \% \mathrm{Cl}, 67.6-74.4)$ and $67.0 \%(95 \% \mathrm{Cl}$, 
62.4-71.6), respectively. The 10-year overall survival rate was $74.9 \%(95 \% \mathrm{Cl}, 71.7-$ 78.1) after $\mathrm{BCT}$ and $71.2 \%(95 \% \mathrm{Cl}, 66.4-76.0)$ after mastectomy $(\mathrm{P}=0.215)$.

A stratified analysis according to tumor size (pT1 or pT2) and nodal status (pN0 and pN1-2) was performed, in which four strata were created: pT1-pN0, pT2pN0, pT1-pN1-2 and pT2 and pN1-2. In none of these four strata a statistically significant difference was observed in the distant recurrence-free survival between the patients undergoing BCT versus those with mastectomy, with P-values of 0.52 , $0.17,0.72$ and 0.64 , respectively.

In the first seven years after treatment, distant recurrence risk was significantly lower for the patients treated with $\mathrm{BCT}(\mathrm{P}=0.009)$. However, for the patients surviving without distant metastases until the seventh year of follow-up, the risk of developing distant disease is lower for the patients with mastectomy $(P=0.044)$. This reversal of the risk was also expressed by the distant disease hazard ratio for BCT compared to mastectomy, which was $0.75(95 \% \mathrm{Cl}, 0.61-0.93)$ during the first seven years of follow-up and $1.96(95 \% \mathrm{Cl}, 1.02-3.76)$ for the patients followed from seven years onward until censoring.

A significant improvement in the distant recurrence-free survival was observed during the study period (Figure 3). The 5-year distant recurrence-free survival improved from $72.2 \%(95 \% \mathrm{Cl}, 67.9-76.5)$ in the period $1988-1993$ to $84.8 \%(95 \% \mathrm{Cl}$, 81.0-88.6) in the period 2000-2005 (HR 0.61 (95\% Cl, 0.45-0.82) (Table 3). Other independent favourable prognostic factors were: a negative axillary nodal status, a tumor size of $2 \mathrm{~cm}$ or less and the use of adjuvant systemic treatment.

Also the multivariate analysis showed no statistically significant difference in distant recurrence-free survival between patients treated with BCT and mastectomy (HR, 0.97; 95\% Cl, 0.78-1.20). 


\section{Discussion}

The current study is one of the few studies focussing on young women with early stage breast cancer, comparing local control and survival after BCT and mastectomy.

Our results indicate a worse local control after BCT with a linearly increasing cumulative risk of developing a local relapse even after more than 15 years of followup, whereas a plateau was reached after 6 years for the patients treated with mastectomy. Despite the more favourable stage distribution of the patients who underwent BCT, disease-free survival at 10 years was similar for both treatment groups. The local relapse rate after BCT showed a decreasing trend during the study period but still remains at $1 \%$ annually for the patients treated in the period 2000 2005. We also noted a significant decrease of the distant recurrence rate over time, associated with increased use of systemic therapy, irrespective of the type of surgery.

Many studies on BCT have shown that young women have an increased local relapse risk compared to older women [6-10,21]. However, few data are available from studies in young women on treatment outcomes after BCT compared to mastectomy. Our data show that local relapses keep on occurring after BCT, even after prolonged follow up. This continuing risk was previously reported by Kreike et al who report 10 - and 15 -year local relapse-rates of $9.3 \%$ and $13.8 \%$, respectively, in a cohort of 1024 patients with a mean age of 50 years [22]. A possible explanation for at least part of the late local relapses is the occurrence of new primary tumors.

Minimising the risk of local relapse remains an important clinical issue. The EBCTCG meta-analysis has shown that local control has an influence on long term breast 
cancer related mortality: for every 4 local relapses prevented at 5 years, 1 breast cancer related death is avoided at 15 years [23]. Punglia et al emphasize the importance of a careful selection of patients for BCT as this strategy leads to a decrease in breast-cancer and overall mortality [24]. Although the proportion of local relapses is higher after $\mathrm{BCT}$, studies among young women show no difference in distant recurrence-free survival $[17,15]$. Neither did we find a significant difference with a distant recurrence-free survival at 10 year of $67.0 \%$ after mastectomy and $71.1 \%$ after BCT. The multivariate analysis also showed no difference in distant recurrence-free survival after treatment with $\mathrm{BCT}$ and mastectomy. Results from retrospective studies are harder to interpret than results from randomised controlled studies, because of a possible bias due to baseline characteristics and the selection of treatments. However, randomized studies were not able to give a definitive answer and new randomized controlled trials are hard to imagine. Our study is the largest study with long-term follow-up comparing the outcome after BCT and mastectomy in young women with early-stage breast cancer. Moreover, it is population-based and follow up was meticulously done. One could argue that the poor local control after $\mathrm{BCT}$ is dominated by a group of patients treated rather shortly after the introduction of BCT in The Netherlands, when less attention was given, for example, to preoperative imaging of the tumor and inking of surgical margins (both invasive and DCIS). Fact is however, that a poor local tumor control was also observed in the patients treated in the second period (1994-1999) (Table 2) Fortunately, in the period 2000-2005, we observed a clear trend towards improved local control. There are several factors which could have contributed to this improvement. First of all, the awareness of different risk factors for local relapse after BCT, not only may have led to a more stringent selection of patients for BCT [25], but also to a certain reluctance 
towards treating young women with BCT. Over time, the BCT rate decreased from $69 \%$ to $55 \%$. Secondly, improvements in the locoregional treatment of breast cancer have taken place over the past decades. However, the most important reason for the better local control is the increased use of adjuvant systemic treatment. Table 2 shows a significant increase in local tumor control over time for patients treated with BCT. This can be largely explained by the increasing proportion of node negative patients receiving adjuvant systemic therapy. In the period 1994-1999 15\% of node negative patients received adjuvant systemic therapy, which increased to $60 \%$ in the period 2000-2005. Apart from this, we did not notice an additional influence of second or third generation regimens over first generation regimens on the local relapse rate. Our results, showing the importance of adjuvant systemic treatment and its potential to decrease the risk of local relapse, are in line with other studies $[7,13,23,26-28]$.Patient and tumor related risk factors for local relapse besides young age, are high tumor grade, positive excision margin, and lymphovascular invasion (LVI). In our series, $90 \%$ of the patients had a reported complete tumor excision and of all local relapses, $92 \%$ occurred in patients with a microscopically complete excision. This is in line with the results from Jones et al where only young age, grade 3, the lack of systemic treatment and the omission of a boost dose were found to be independent prognostic factors for local relapses after BCT [10]. Data on LVI and tumor grade were not or only partly available in our material.

Local control is a result of the interaction between tumor remnants, treatment and tumor biology. An ipsilateral breast tumor recurrence (IBTR) can be a new primary tumor or the result of outgrowth of a tumor remnant in the treated breast, a so called true recurrence. New primary tumors often appear later in time and there is some proof that they have a more favorable prognosis than true recurrences. 
Molecular clonality assays can help to establish the type of IBTR [29,30], but larger studies are needed to draw conclusions about their potential prognostic and therapeutic value.

Recently, studies of tumor biology by gene expression micro-array technology have demonstrated patterns correlating with breast cancer in young women [31] and even local relapses in young women [32]. However, this new technology is not yet robust enough for clinical use with regard to local treatment decisions until results from ongoing prospective clinical trials are available. Genetic alterations in histologically normal tissue adjacent to the breast tumor, such as chromosomal instability en DNA hypermethylation, could also play a role [33,34].

For the patients in our study information about BRCA1/2 status was largely unknown. Population-based data indicate that approximately $10 \%$ of the breast cancers in women younger than 40 years are related to a BRCA1 or BRCA2 mutation [35].Although women who carry BRCA mutations have a very high risk of developing breast cancer, there is no convincing evidence that their risk of developing local relapse after BCT is significantly different from the risk in non-carriers [36-38]. The risk of developing a contralateral breast cancer is, on the other hand, much higher than in non-carriers $[36,38,37]$.

The categorisation into breast cancer subtypes, based on the combination of hormonal receptor status and HER-2 status, may be predictive for recurrence risks and survival. Kyndi et al found a significantly lower locoregional recurrence rate and a significant survival improvement in hormone receptor positive patients treated with mastectomy and radiation therapy whereas in triple negative and hormone receptor negative patients the benefit of radiotherapy was much less pronounced [39]. In 
HER-2 positive patients, trastuzumab reduces the risk of locoregional recurrence by $57 \%[40]$.

In summary, local control after BCT in patients $\leq 40$ years is significantly worse than after mastectomy with local relapses continuing to occur during long-term followup. Local relapses might negatively influence the long term survival of patients with breast cancer, although we were unable to demonstrate this. Adjuvant systemic therapy has been the main contributor to the observed improvement of local control over the past decades. Nevertheless, the local relapse rate remains approximately $1 \%$ per year, which underlines the necessity of improvement and continuation of follow-up. Whether the marked reluctance against BCT in young women is less appropriate with current, more potent systemic treatment has to be confirmed. The biggest challenge still remaining is to define the most appropriate local treatment for each individual patient by establishing new predictors for local relapse after BCT.

\section{Conflict of interest statement}

No conflict of interest declared for the authors Dr. M.J.C. van der Sangen, Dr. F.M.M. van de Wiel, Dr. P.M.P. Poortmans, Prof. Dr. V.C.G. Tjan-Heijnen, Dr. G.A.P. Nieuwenhuijzen, Dr. R.M.H. Roumen, Dr. M.F. Ernst, Dr. M.C.B.J.E. Tutein Nolthenius-Puylaert and Dr. A.C. Voogd. 


\section{References}

1. Veronesi U, Cascinelli N, Mariani L, Grecco M, Saccozzi R, Luini A, Aguilar M, Marubini E (2002) Twenty-year follow-up of a randomized study comparing breastconservin surgery with radical mastectomy for early breast cancer. N Engl J Med 347 (16):1227-1232

2. Fisher B, Anderson S, Bryant J, Margolese RG, Deutsch M, Fisher ER, Jeong J-H, Wolmark N (2002) Twenty-year follow-up of a randomized trial comparing total mastectomy, lumpectomy, and lumpectomy plus irradiation for the treatment of invasive breast cancer. N Engl J Med 347 (16)

3. Van Dongen JA, Voogd AC, Fentiman IS, Legrand C, Sylvester RJ, Tong D, Van der Schueren E, Helle PA, Van Zijl K, Bartelink H (2000) Long-term results of a randomized trial comparing breast-conserving therapy with mastectomy: European organization for research and treatment of cancer 10801 trial. J Natl Cancer Inst 92 (14):1143-1150

4. Jacobson JA, Danforh DN, Cowan KH, D'Angelo T, Steinberg SM, Pierce L, Lippman ME, Lichter AS, Glatstein E, Okunieff P (1995) Ten-year results of a comparison of conservation with mastectomy in the treatment of stage i and ii breast cancer. N Engl J Med 332 (14):907-911

5. Blichert-T oft M, Rose C, Andersen JA, Overgaard M, Axelsson CK, Andersen KW, Mouridsen HT (1992) Danish randomized trial comparing breast conservation therapy with mastectomy: Six years of life-table analysis. Danish breast cancer cooperative group. J Natl Cancer Inst Monogr (11):19-25

6. Voogd AC, Nielsen M, Peterse JL, Blichert-Toft M, Bartelink H, Overgaard M, Van Tienhoven G, West Andersen K, Sylvester RJ, Van Dongen JA (2001) Differences in 
risk factors for local and distant recurrence after breast-conserving therapy or mastectomy for stage i and ii breast cancer: Pooled results for two large european randomized trials. J Clin Oncol 19 (6):1688-1697

7. De Bock GH, van der Hage JA, Putter H, Bonnema J, Bartelink H, Van de Velde CJ (2006) Isolated loco-regional recurrence of breast cancer is more common in young patients and following breast conserving therapy: Long-term results of european organisation for research and treatment of cancer studies. Eur J Cancer 42 (3):351-356

8. Vrieling C, Fourquet A, Hoogenraad WJ, Horiot JC, Jager JJ, Bing Oei S, Peterse HL, Pierart M, Poortmans PM, Struikmans H, Van den Bogaert W, Bartelink H (2003) Can patient-, treatment- and pathology-related characteristics explain the high local recurrence rate following breast-conserving therapy in young patients? Eur $\mathrm{J}$ Cancer $39(7): 932-944$

9. Elkhuizen PHM, Van de Vijver MJ, Hermans J, Zonderland HM, Van de Velde CJ, Leer J-WH (1998) Local recurrence after breast-conserving therapy for invasive breast cancer: High incidence in young patients and association with poor survival. Int J Radiat Oncol Biol Phys 40 (4):859-867

10. Jones HA, Antonini N, Hart AA, Peterse JL, Horiot JC, Collin F, Poortmans PM, Oei SB, Collette L, Struikmans H, Van den Bogaert WF, Fourquet A, Jager JJ, Schinagl DA, Wárlám-Rodenhuis CC, Bartelink H (2009) Impact of pathological characteristics on local relapse after breast-conserving therapy: A subgroup analysis of the eortc boost versus no boost trial. J Clin Oncol 27 (30):4939-4947 11. Jobsen JJ, Van der Palen J, Ong F, Meerwaldt JH (2003) The value of a positive margin for invasive carcinoma in breast-conservative treatment in relation to local 
recurrence is limited to young women only. Int J Radiat Oncol Biol Phys 57 (3):724731

12. Arriagada R, Lê MG, Guinebretière J-M, Dunant A, Rochard F, Tursz T (2003) Late local recurrences in a randomised trial comparing conservative treatment with total mastectomy in early breast cancer patients. Annals of Oncology 14 (11):16171622

13. Van der Leest M, Evers L, Van der Sangen MJC, Poortmans PM, Van de PollFranse LV, Vulto AJ, Nieuwenhuijzen GAP, Brenninkmeijer SJ, Creemers G, Voogd AC (2007) The safety of breast-conserving therapy in patients with breast cancer aged $\leq 40$ years. Cancer 109 (10):1957-1964

14. Lammers EJR, Huibers P, Van der Sangen MJC, Van de Poll-Franse LV, Poortmans PM, Ernst MF, Lemaire BMD, Meijs CMEM, H.K.S. N, Voogd AC (2009) Factors contributing to improved local control after mastectomy in patients witch breast cancer aged 40 years or younger. Breast 15. Coulombe G, Tyldesley S, Speers C, Paltiel C, Aquino-Parsons C, Bernstein V, Truong P, Keyes M, Olivotto IA (2007) Is mastectomy superior to breast-conserving treatment for young women? Int J Radiat Oncol Biol Phys 67 (5):1282-1290 16. Beadle BM, Woodward WA, Tucker SL, Outlaw ED, Allen PK, Oh JL, Strom EA, Perkins GH, Tereffe W, Yu T, Meric-Bernstam F, Litton JK, Buchholz TA (2009) Tenyear recurrence rates in young women with breast cancer by locoregional treatment approuch. Int J Radiat Oncol Biol Phys 73 (3):734-744

17. Kroman N, Holtveg H, Wohlfart J, Jensen M-B, Mouridsen HT, Blichert-Toft M, Melbye M (2004) Effect of breast-conserving therapy versus radical mastectomy on prognosis for young women with breast carcinoma. Cancer 100 (4):688-693 
18. Bontenbal M, Nortier JW, Beex LV, Bakker P, Hupperets PS, Nooij MA, Van Veelen H, Vreugdenhil G, Richel DJ, Bijham GH (2000) Adjuvant systemic therapy for patients with resectable breast cancer: Guideline from the dutch national breast cancer platform and the dutch society for medical oncology. Ned Tijdschr Geneeskd $144(21): 984-989$

19. Goldhirsch A, Glick JH, Gelber RD, Senn HJ (1998) Meeting highlights:

International consensus panel on the treatment of primary breast cancer. J Natl Cancer Inst 90 (21):1601-1608

20. Goldhirsch A, Glick JH, Gelber RD, Coates AS, Senn HJ (2001) Meeting highlights: International consensus panel on the treatment of primary breast cancer. Seventh international conference on adjuvant therapy of primary breast cancer. J Clin Oncol 19 (18):3817-3827

21. Zhou P, Gautam S, Recht A (2007) Factors affecting outcome for young women with early stage invasive breast cancer treated with breast-conserving therapy. Breast cancer research and treatment 101 (1):51-57 22. Kreike B, Hart AMA, Van de Velde T, Borger J, Peterse H, Rutgers E, Bartelink H, Van de Vijver MJ (2008) Continuing risk of ipsilateral breast relapse after breastconserving therapy at long-term follow-up. Int J Radiat Oncol Biol Phys 71 (4):10141021

23. Clarke M, Collins R, Darby S, Davies C, Elphinstone P, Evans E, Godwin J, Gray R, Hicks C, James S, MacKinnon E, McGale P, McHugh T, Peto R, Taylor C, Wang $Y(2005)$ Effects of radiotherapy and differences in the extent of surgery for early breast cancer on local recurrence and 15-year survival: An overview of the randomised trials. Lancet 366 (9503):2087-2106 
24. Punglia RS, Morrow M, Winer EP, Harris JR (2007) Local therapy and survival in breast cancer. N Engl J Med 356 (23):2399-2405

25. Voogd AC, Repelaer van Driel OJ, Roumen RMH, Crommelin MA, Van Beek MWPM, Coebergh JWW (1997) Changing attitudes towards breast-conserving treatment of early breast cancer in the south-eastern netherlands: Results of a survey among surgeons and a registry-based analysis of patterns of care. Eur J Surg Oncol $23(2): 134-138$

26. Buchholz TA, Tucker SL, Erwin J, Mathur D, Strom EA, McNeese MD, Hortobagyi GN, Cristofanilli M, Esteva FJ, Newman L, Singletary ES, Buzdar AU, Hunt KK (2001) Impact of systemic treatment on local control for patients with lymph nodenegative breast cancer treated with breast-conservation therapy. J Clin Oncol 19 (8):2240-2246

27. Kroman N, Jensen M-B, Wohlfart J, Mouridsen HT, Andersen PK, Melbye M (2000) Factors influencing the effect of age on prognosis in breast cancer: Population based study. BMJ 320 (7233):474-478

28. Park CC, Mitsumori M, Nixon A, Recht A, Connoly J, Gelman R, Silver B, Hetelekidis S, Abner A, Harris JR, Schnitt SJ (2000) Outcome at 8 years after breastconserving surgery and radiation therapy for invasive breast cancer: Influence of margin status and systemic therapy on local recurrence. J Clin Oncol 18 (8):16681675

29. McGrath S, Antonucci J, Goldstein N, Wallace M, Mitchell C, Grills I, Jolly S, Kestin L, Vicini F (2010) Long-term patterns of in-breast failure in patients with early stage breast cancer treated with breast-conserving therapy: A molecular based clonality evaluation. American journal of clinical oncology 33 (1):17-22 
30. Schlechter BL, Yang Q, Larson PS, Golubeva A, Blanchard RA, de las Morenas A, Rosenberg CL (2004) Quantitative DNA fingerprinting may distinguish new primary breast cancer from disease recurrence. J Clin Oncol 22 (10):1830-1838

31. Anders CK, Hsu DS, Broadwater G, Acharya CR, Foekens JA, Zhang Y, Wang Y, Marcom PK, Marks JR, Febbo PG, Nevins JR, Potti A, Blackwell KL (2008) Young age at diagnosis correlates with worse prognosis and defines a subset of breast cancers with shares patterns of gene expression. J Clin Oncol 26 (20):3324-3330 32. Kreike B, Halfwerk H, Armstrong N, Bult P, Foekens JA, Veltkamp SC, Nuyten DSA, Bartelink H, Van de Vijver MJ (2009) Local recurrence after breast-conserving therapy in relation to gene expression patterns in a large series of patients. Clin Cancer Res 15 (12):4181-4190

33. Ellsworth DL, Ellsworth RE, Love B, Deyarmin B, Lubert SM, Mittal V, Shriver CD (2004) Genomic patterns of allelic imbalance in disease free tissue adjacent to primary breast carcinomas. Breast cancer research and treatment 88 (2):131-139 34. Yan PS, Venkataramu C, Ibrahim A, Liu JC, Shen RZ, Diaz NM, Centeno B, Weber F, Leu YW, Shapiro CL, Eng C, Yeatman TJ, Huang THM (2006) Mapping geographic zones of cancer risk with epigenetic biomarkers in normal breast tissue. Clin Cancer Res 12 (22):6626-6636

35. De Sanjosé S, Léoné M, Bérez V, Izquierdo A, Font R, Brunet JM, Louat T, Vilardell L, Borras J, Viladiu P, Bosch FX, Lenoir GM, Sinilnikova OM (2003) Prevalence of brca1 and brca2 germline mutations in young breast cancer patients: A population based study. International Journal of Cancer 106 (4):588-593

36. Pierce LJ, Levin AM, Rebbeck TR, Ben-David MA, Friedman E, Solin LJ, Harris EE, Gaffney DK, Haffty BG, Dawson LA, Narod SA, Olivotto IA, Eisen A, Whelan TJ, Olopade OI, Isaacs C, Merajver SD, Wong JS, Garber JE, Weber BL (2006) Ten- 
year multi-institutional results of breast-conserving surgery and radiotherapy in brca1/2-associated stage i/ii breast cancer. J Clin Oncol 24 (16):2437-2443 37. Haffty BG, Harrold E, Khan AJ, Pathare P, Smith TE, Turner BC, Glazer PM, Ward B, Carter D, Matloff E, Bale AE, Alvarez-Franco M (2002) Outcome of conservatively managed early-onset breast cancer by brca1/2 status. Lancet 359 $(9316): 1471-1477$

38. Alpert TE, Haffty BG (2004) Conservative management of breast cancer in brca1/2 mutation carriers. Clinical breast cancer 5 (1):37-42

39. Kyndi M, Sorensen FB, Knudsen H, Overgaard M, Melgaard Nielsen $\mathrm{H}$, Overgaard M (2008) Estrogen receptor, progesterone receptor, her-2, and response to mastectomy radiotherapy in high-risk breast cancer: The danish breast cancer cooperative group. J Clin Oncol 26 (9):1419-1426

40. Romond EH, Perez EA, Bryant J, Suman VJ, Geyer CE, Davidson NE, Tan-Chiu E, Martino S, Paik S, Kaufman PA, Swain SM, Pisansky TM, Fehrenbacher L, Kutteh LA, Vogel VG, Visscher DW, Yothers G, Jenkins RB, Brown AM, Dakhil SR, Mamounas EP, Lingle WL, Klein PM, Ingle JN, Wolmark N (2005) Trastuzumab plus adjuvant chemotherapy for operable her2-positive breast cancer. N Engl J Med 353 $(16): 1673-1684$ 


\section{Legends to figures}

Fig. 1a, 1b Proportion of patients receiving adjuvant systemic treatment, according to lymph node-status and period of treatment

Fig. 2a Actuarial local tumor control in patients aged $\leq 40$ years, according to local treatment. BCT, breast-conserving treatment

Fig. 2b Actuarial local tumor control in patients aged $\leq 40$ years, according to local treatment and adjuvant systemic therapy. BCT, breast-conserving treatment; MAS, mastectomy; ST, adjuvant systemic treatment

Fig. 3 Actuarial distant recurrence-free survival in patients aged $\leq 40$ years, according to local treatment. BCT, breast-conserving treatment 


\section{Table 1}

General characteristics of patients aged 40 years or younger undergoing breast-conserving therapy (BCT) or mastectomy in the period 1988-2005.

\begin{tabular}{|c|c|c|c|c|c|}
\hline \multirow[t]{2}{*}{ Characteristic } & \multicolumn{2}{|c|}{$B C T(n=889)$} & \multicolumn{2}{|c|}{$\begin{array}{l}\text { Mastectomy } \\
(n=562)\end{array}$} & \multirow[t]{2}{*}{ P-value } \\
\hline & $N$ & $(\%)$ & $N$ & (\%) & \\
\hline Age (yrs) & & & & & 0.048 \\
\hline$\leq 30$ & 69 & (8) & 65 & (12) & \\
\hline $31-35$ & 253 & (28) & 149 & (27) & \\
\hline $36-40$ & 567 & (64) & 348 & (62) & \\
\hline Period & & & & & $<.0001$ \\
\hline 1988-1993 & 309 & (35) & 136 & (24) & \\
\hline 1994-1999 & 306 & (34) & 198 & (35) & \\
\hline $2000-2005$ & 274 & (31) & 228 & (51) & \\
\hline Tumor size (pT) & & & & & $<.0001$ \\
\hline $\mathrm{T} 1$ & 610 & (70) & 227 & $(42)$ & \\
\hline $\mathrm{T} 2$ & 266 & (30) & 313 & (58) & \\
\hline Unknown & 13 & & 22 & & \\
\hline Nodal status (pN) & & & & & $<.0001$ \\
\hline $\mathrm{pN}-$ & 581 & (66) & 271 & (48) & \\
\hline $\mathrm{pN}+$ & 304 & (34) & 288 & (52) & \\
\hline Unknown & 4 & & 3 & & \\
\hline Tumor type & & & & & $<.0001$ \\
\hline Ductal & 802 & (90) & 478 & (85) & \\
\hline Lobular/mixed & 60 & $(7)$ & 81 & (14) & \\
\hline Other & 27 & (3) & 3 & $(1)$ & \\
\hline Grade & & & & & 0.016 \\
\hline Good & 52 & (12) & 30 & (8) & \\
\hline Intermediate & 151 & (34) & 109 & (29) & \\
\hline Poor & 239 & (54) & 242 & (64) & \\
\hline Unknown & 447 & & 181 & & \\
\hline Estrogen receptor & & & & & 0.389 \\
\hline Negative & 255 & (36) & 158 & (32) & \\
\hline Positive & 455 & (64) & 314 & (68) & \\
\hline Unknown & 179 & & 90 & & \\
\hline Microscopic completeness of tumor excision & & & & & $<.0001$ \\
\hline Complete & 836 & (94) & 477 & (85) & \\
\hline Incomplete & 39 & (4) & 10 & $(2)$ & \\
\hline Doubtful or unknown & 14 & (2) & 75 & (12) & \\
\hline Radiotherapy & & & & & $<.0001$ \\
\hline Yes & 889 & $(100)$ & 206 & (37) & \\
\hline No & 0 & $(0)$ & 355 & (63) & \\
\hline Unknown & & & 1 & & \\
\hline
\end{tabular}


Table 1 (continued)

\begin{tabular}{|c|c|c|c|c|c|}
\hline 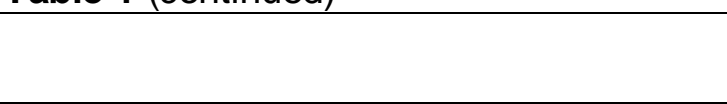 & \multicolumn{2}{|c|}{ BCT $(n=889)$} & \multicolumn{2}{|c|}{$\begin{array}{l}\text { Mastectomy } \\
(n=562)\end{array}$} & \multirow[t]{2}{*}{$P$} \\
\hline & $\mathrm{N}$ & $(\%)$ & $\mathrm{N}$ & (\%) & \\
\hline Adjuvant systemic treatment & & & & & $<.0001$ \\
\hline Chemotherapy & 233 & (26) & 205 & (37) & \\
\hline Chemotherapy and endocrine treatment & 145 & $(16)$ & 154 & $(27)$ & \\
\hline Endocrine treatment & 26 & (3) & 4 & (1) & \\
\hline None & 483 & (54) & 198 & (35) & \\
\hline Unknown & 2 & & 1 & & \\
\hline
\end{tabular}

\section{Table 2}

5-, 10- and 15-year actuarial risks of local recurrence after BCT, according to patient, tumor and treatment characteristics

\begin{tabular}{|c|c|c|c|c|c|c|}
\hline Characteristic & No. & $\begin{array}{l}\text { No. } \\
\text { LRs }\end{array}$ & $\begin{array}{l}\text { 5-year rate } \\
\text { (SE) }\end{array}$ & $\begin{array}{l}\text { 10-year } \\
\text { rate } \\
\text { (SE) }\end{array}$ & $\begin{array}{l}\text { 15-year rate } \\
\text { (SE) }\end{array}$ & $P-v$ \\
\hline \multicolumn{7}{|l|}{ Age (years) } \\
\hline$\leq 30$ & 69 & 9 & $2.2(2.2)$ & $16.9(6.4)$ & $28.4(9.5)$ & .5 \\
\hline $31-35$ & 253 & 44 & $9.3(2.0)$ & $23.6(3.6)$ & $29.9(4.5)$ & \\
\hline $36-40$ & 567 & 82 & $8.4(1.3)$ & $15.5(2.0)$ & $26.6(3.0)$ & \\
\hline \multicolumn{7}{|l|}{ Year of BCT } \\
\hline 1988-1993 & 309 & 74 & $11.2(2.0)$ & $20.2(2.7)$ & $30.3(3.2)$ & .03 \\
\hline 1994-1999 & 306 & 50 & $8.8(1.7)$ & $20.1(2.7)$ & n.a. & \\
\hline $2000-2005$ & 274 & 11 & $3.8(1.3)$ & n.a. & n.a. & \\
\hline \multicolumn{7}{|c|}{ Pathological T-classification (pT) } \\
\hline pT1 & 610 & 99 & $8.5(1.2)$ & $18.7(2.1)$ & $27.8(2.9)$ & .5 \\
\hline рT2 & 266 & 32 & $6.0(1.7)$ & $16.4(3.2)$ & $27.7(5.6)$ & \\
\hline \multicolumn{7}{|c|}{ Pathological N-classification (pN) } \\
\hline pNO & 581 & 112 & $10.0(1.4)$ & $21.4(2.2)$ & $33.0(3.2)$ & .00 \\
\hline pN1-2 & 304 & 23 & $4.5(1.4)$ & $10.6(2.5)$ & $13.9(3.4)$ & \\
\hline \multicolumn{7}{|l|}{ Radiotherapy boost } \\
\hline Yes & 815 & 113 & $8.0(1.1)$ & $17.9(1.8)$ & $26.6(2.7)$ & 0 . \\
\hline No & 74 & 22 & $11.4(4.1)$ & $24.1(5.7)$ & $37.9(7.5)$ & \\
\hline \multicolumn{7}{|c|}{ Adjuvant systemic therapy } \\
\hline Yes & 404 & 30 & $4.2(1.1)$ & $11.3(2.4)$ & $16.1(3.5)$ & .00 \\
\hline No & 483 & 105 & $11.3(1.6)$ & $22.3(2.3)$ & $32.9(3.1)$ & \\
\hline \multicolumn{7}{|c|}{ Microscopic completeness of tumor } \\
\hline Complete & 836 & 122 & $7.6(1.0)$ & $16.9(1.7)$ & $26.9(2.6)$ & .01 \\
\hline Incomplete / doubtful & 39 & 10 & $25.1(8.3)$ & $38.9(11.1)$ & n.a. & \\
\hline
\end{tabular}

n.a. not available

Table 3

Multivariable analysis for time until distant metastases for patients aged 40 years or younger $(n=1408)$ 


\begin{tabular}{llll}
\hline $\begin{array}{l}\text { Period of diagnosis } \\
\text { 1988-1993 }\end{array}$ & 1 (Ref) & & \\
$1994-1999$ & 0.75 & $(0.60-0.95)$ & .016 \\
$2000-2005$ & 0.61 & $(0.45-0.82)$ & .001 \\
$\begin{array}{l}\text { Age at diagnosis (years) } \\
\quad \leq 35\end{array}$ & 1 (Ref) & & \\
$\quad \begin{array}{lll}\text { 36-40 } \\
\text { Pathologic tumor classification }\end{array}$ & 1.12 & $(0.91-1.37)$ & .296 \\
$\quad$ pT1 & 1 (Ref) & & \\
pT2 & 1.39 & $(1.13-1.70)$ & .002 \\
$\begin{array}{l}\text { Pathologic lymph node status } \\
\text { pN0 }\end{array}$ & 1 (Ref) & & \\
$\quad$ pN1-2 & 2.51 & $(1.85-3.40)$ & $<.0001$ \\
$\begin{array}{l}\text { Type of surgery } \\
\text { Mastectomy }\end{array}$ & 1 (Ref) & & \\
$\quad$ BCT & 0.97 & $(0.78-1.20)$ & .771 \\
Adjuvant systemic therapy & & & \\
$\quad$ No & 1 (Ref) & & \\
$\quad$ Yes & 0.66 & $(0.48-0.91)$ & .012 \\
\hline
\end{tabular}

